\title{
VITAMIN D DEFICIENCY AND ITS IMPORTANCE - A GLOBAL PROBLEM OF TODAY, REALISTIC OR NOT?
}

\author{
Olivera Z. Milovanovic
}

${ }^{1}$ Faculty of Medical Science, University of Kragujevac, Department of Pharmacy

\author{
DEFICIJENCIJA VITAMINA D I NJEN ZNAČAJ \\ - GLOBALNI PROBLEM DANAŠNJICE, REALNO ILI NE? \\ Olivera Z. Milovanović
}

${ }^{1}$ Fakultet medicinskih nauka, Univerzitet u Kragujevcu, odsek Farmacija

\section{ABSTRACT}

Vitamin D, also known as the "sun vitamin" in the literature, has been examined for many years and still arouses researchers' interest due to the pleiotropic effects achieved in the human body. Because of the influence on mineral homeostasis, the initially observed effects of vitamin $D$ on the prevention and treatment of rickets, have now been extended to a large number of diseases with different aetiologies such as cardiovascular, autoimmune, endocrine, infectious, neurological, malignant and other diseases. Due to the large number of experimental studies in animals and humans, we have exact information about the role of vitamin $D$ in many of these conditions. Reaching an adequate level of $25(\mathrm{OH}) \mathrm{D}$ in the human body is a basic requirement for the realization of these effects; $25(\mathrm{OH}) \mathrm{D}$ is a metabolic product that reflects the vitamin $D$ status but that does not have any biological activity. The biological activities of vitamin D can occur only after the formation of a second metabolic product, $1,25(\mathrm{OH})_{2} \mathrm{D}$, in the kidneys. The three main sources of acquiring vitamin $D$ are through food, skin and supplementation. Food is not a rich source of vitamin $D$; it is clear that the most important influences to achieve an optimal vitamin D status in the human body are vitamin $D$ synthesis at the skin and adequate supplementation intake. An alarming fact is that vitamin D deficiency is detected in an increasing number of people from one day to another in the general world population and that this condition has pandemic dimensions. Introducing the beneficial effects and sources of vitamin $D$ to the general population and to medical experts with adequate supplementation regime can decrease the number of people who are vitamin $D$ deficient.

Keywords: vitamin D, physiological effects, pharmacokinetics characteristics, vitamin D deficiency

\section{SAŽETAK}

Vitamin D, u literaturi poznat kao "vitamin sunca", iako je već dugo godina ispitivan i dalje pobuduje interesovanje kod naučnika usled plejade efekata koje ostvaruje u humanom organizmu. Prvobitno dokazani efekti vitamina $D$ u prevenciji $i$ terapiji rahitisa usled uticaja na postizanje mineralne homeostaze danas su prošireni na veliki broj bolesti različite etiologije kao što su kardiovaskularna, autoimunska, endokrinološka, infektivna, nerološka, maligna i druga oboljenja. Zahvaljujući velikom broju ekperimentalnih studija kako na animalnom tako $i$ na humanom modelu danas se za veliki broj navedenih oboljenja zna tačan mehanizam dejstva vitamina D. Za ispoljavanje navedenih efekata osnovni preduslov je dostizanje optimalnog nivoa 25(OH)D, prvog metaboličkog produkta vitamina $D$, koji iako služi kao osnovni parameter za odredivanje statusa vitamina D kod ljudi ne predstalja biološki aktivnu formu vitamina D. Da bi se ispoljili navedeni biološki efekti vitamina $D$ neophodno je formiranje sekundarnog metaboličkog produkta $1,25(\mathrm{OH})_{2} D$. Tri osnovna izvora vitamina D su koža, hrana $i$ suplementi. Kako hrana sadrži vitamin D u mali količinama, jasno je da na adekvatan status vitamina D najviše utiče sinteza vitamina $D$ u koži i uzimanje određene doze suplemenata. Alarmirajući podatak je da iz dana u dan raste broj svetske populacije kod koje je utvrđeno postojanje hipovitaminoze D $i$ da ova pojava trenutno ima pandemijske razmere. Upoznavanjem opšte javnosti sa korisnim efektima vitamina D i njegovim izvorima a stručne javnosti sa adekvatnim suplementacionim dozama može se uticati na smanjenje broja deficijentnih osoba kako u našoj zemlji tako i svetu.

Ključne reči: vitamin D, fiziološki efekti, farkakokinetke karakteristike, deficijencija vitamina $D$

\section{ำ}

ABBREVIATIONS

cAMP- cyclic adenosine monophosphate CRE- cyclic adenosine monophosphate response element FGF23- fibroblast-like growth factor-23
PTH- parathyroid hormone

TGF $\beta 1$ - transforming growth factor $\beta 1$ VDBP- vitamin D binding protein
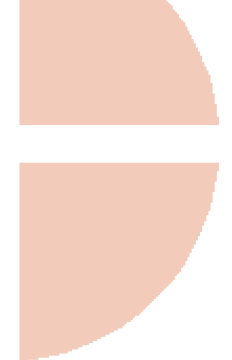


\section{INTRODUCTION}

Vitamin D, a lipophilic vitamin, has been examined since the 20th century and continues to be a focus of scientific research due to it pleiotropic effects in the human body. The roles of vitamin $\mathrm{D}$ have been observed in a large number of epidemiological and experimental studies that confirmed correlations between vitamin D status and both acute and chronic diseases. The primary recognized effects of vitamin $\mathrm{D}$ on mineral homeostasis and consequently on bone health have now expanded to include diseases such as autoimmune, anti-inflammatory, cardiovascular, cancer, diabetes, infectious, psychiatric and others (1-5).

The most important vitamin D discovery from a historical perspective was in 1922, when McCollum, an American biochemist, was performing experimental work on rats with rickets with his team and noted a substance in fish oil that could prevent and treat this bone disease, he called this substance vitamin D. Simultaneously, Huldschinsky observed the benefits of UV radiation in children with rickets. Both events intrigued the scientific community to specify why these events happened and triggered further testing that finally resulted in the precise definition of the chemical structure of vitamin D after several years of work $(6,7)$.

There are several different structural forms of vitamin D, but two forms are separated from that group according to their physiological importance for the human body; those two forms are vitamin D2 (ergocalciferol) and vitamin D3 (cholecalciferol). In addition to the differences in chemical structure, they have various origins: ergocalciferol has a plant origin while cholecalciferol has an animal and human origin. According to the results of clinical trials, cholecalciferol exhibits more potent clinical efficiency than ergocalciferol due to its structural and metabolic differences, which can be important for providing recommendations about vitamin D supplementation for some indications (8).

The two cardinal causes of deficiency include insufficient exposure to sunlight and inadequate nutritional intake of vitamin D, but there are also many factors with different mechanisms that lead to this deficiency.

In this review article, we summarize the available scientific accomplishments related to vitamin D and its deficiency and the government guidelines in Europe and other countries.

\section{VITAMIN D SYNTHESIS AND SOURCES}

A characteristic of vitamin $\mathrm{D}$ that makes it unique among vitamins is that it is derived from exogenous and endogenous sources. A large number of observational and clinical trials have revealed that there are three main sources of vitamin D: the skin, certain foods and supplements. The most important of these three sources for achieving the optimal range of $25(\mathrm{OH}) \mathrm{D}$ in the human body is the skin, both in humans and animals (9).

The process of vitamin D synthesis in the skin is multi-step and multifactorial, which makes it significantly difficult to reach an optimal range of $25(\mathrm{OH}) \mathrm{D}$. Twothirds of the concentration of serum 25(OH)D has an endogenous origin, while the remaining one third is exogenous. Although $25(\mathrm{OH}) \mathrm{D}$, as a first metabolic product, is biologically inactive in contrast to $1,25(\mathrm{OH})_{2} \mathrm{D}$, it serves as a key marker to assess the status of vitamin $\mathrm{D}$ in the human body due to pharmacokinetic characteristics such as a half-life from several days to several weeks for this metabolic form, in comparison, the half-life of calcitriol is only a few hours (10).

First information about vitamin $\mathrm{D}$ production in the skin dates back to the beginning of the 20th century with evidence on mammalian skin synthesis, and the complete explanation of this process was revealed to the general public in 1980 by Holick and co-workers (11). As the sun is an unavoidable factor in the synthesis of vitamin D, a common synonym for this vitamin in the medical literature is "sunshine vitamin".

Vitamin D skin production begins with skin exposure to UVB radiation in the range of 290 to $315 \mathrm{~nm}$ when provitamin D, 7-dehydrocholesterol, from the skin is converted to previtamin $\mathrm{D}$, which undergoes thermal isomerization to vitamin D3. It is interesting that the scientific population, after the chemical identification of vitamin D3 at the beginning of the 20th century, considered that this compound was a direct product of provitamin $\mathrm{D}$. This claim was refuted after a solution of 7-dehydrocholesterol was exposed to UV radiation and yielded an unknown compound that was later classified as previtamin D3 (12). Unlike previtamin D3, vitamin D3 is thermostable and does not undergo further isomerisation in the body. Experimental resources demonstrate that the optimal body temperature for the thermal isomerisation of previtamin $\mathrm{D}$ is $37^{\circ} \mathrm{C}$. The only distinction between vitamin D2 and D3 synthesis is in the starting substance (13). An advantage of this multistep reaction is that previtamin D and vitamin $\mathrm{D}$, after prolonged exposure to the sun, absorb UVB radiation and create biologically inactive products such as lumisterol, tachysterol, suprasterol, etc. $(1,4)$. Due to the aforementioned characteristics, prolonged exposure to sunlight is not related to toxic levels of vitamin D3, this finding is substantiated by the results of many clinical trials (14).

Synthesized vitamin D is transported from the skin via the blood to the liver where the hydroxylation reaction occurs by means of the 25-hydroxylase enzyme and is thereafter transported to the kidneys where the second hydroxylation reaction occurs by the 1-alpha-hydroxylase enzyme. The final product of the second hydroxylation is 1,25-dihydroxyvitamin D, calcitriol, which acts as a hormone. This reaction is firmly controlled by the actions of two hormones, parathyroid hormone and fibroblast-like growth factor-23 (FGF23), which have opposing actions. 
Parathyroid hormone up-regulates calcitriol synthesis, and FGF23 down-regulates calcitriol synthesis. In addition to the parathyroid hormone, up regulation is stimulated by low levels of calcium and phosphorous, while down regulation is stimulated by calcitriol itself (15). A precondition for these hydroxylation reactions is the binding of vitamin $\mathrm{D}$ to the vitamin D binding protein (VDBP) in the bloodstream, vitamin D cannot otherwise be transported to the liver and kidney due to its liposolubility. Vitamin D production occurs in extra renal tissue such as the parathyroid glands and the prostate, colon, lung, brain and other tissues in which the aforementioned enzymes were confirmed but present in smaller quantities (4).

Some fish, such as herring, sardines, mackerel, and mushrooms, egg yolk, and offal are some types of food that contain vitamin D at specified amounts. Food is a source of vitamin $\mathrm{D}$ and can influence the serum vitamin $\mathrm{D}$ level in humans, but the list of food that contains this vitamin in certain amounts is scarce. Nutrition cannot offset inadequate endogenous vitamin $\mathrm{D}$ production during a specific period of the year, such as during the winter months $(16,17)$.

As dietary intake of vitamin D may be not adequate, one of the potential ways to achieve a desirable level of vitamin D is supplementation. It is notable that recommendations for supplementation vary from country to country and for different populations. According to the report of the European Food Safety Authority for the adult population, the upper limit for vitamin D supplementation is $100 \mu \mathrm{g} /$ day instead of the former recommendation of 50 $\mu \mathrm{g} /$ day, while the recommended dosage is in the range of 800- $2000 \mathrm{IU} /$ day (20-50 $\mu \mathrm{g} /$ day) (18). Healthcare practitioners should always keep in mind that dosing should be harmonized with the patient's pathophysiological condition in order to avoid potential intoxication due to overdose. The most common sign of vitamin D intoxication is hypercalcemia. The manifestation of hypercalcemia includes symptoms such as lethargy, nausea, vomiting, dehydration, etc. There are sparse clinical data on toxicity. In addition to hypercalcaemia, other conditions that accompany vitamin D toxicity can include hypercalciuria or nephrocalcinosis (18).

\section{PHYSIOLOGICAL AND PHARMACOKINETIC EFFECTS OF VITAMIN D}

In order to understand the role of vitamin $\mathrm{D}$ in the human body, it is necessary to understand its physiological and pharmacokinetic effects. Vitamin D exerts autocrine, paracrine and endocrine effects in the body by binding the vitamin $\mathrm{D}$ receptors that are located in most tissues and organs. Observations of many experimental studies have shown that after the synthesis of $1,25(\mathrm{OH}) \mathrm{D}$, its biological effect is expressed by binding to nuclear vitamin D receptors, leading to complex effects on specific DNA sequences, which consequently influences the transcription of several hundred genes (4).

\section{PHYSIOLOGICAL EFFECTS OF VITAMIN D}

There are a growing number of studies that have emphasised the effects of vitamin D in humans and animals, and this wide range of effects can be divided to skeletal and non-skeletal effects. Skeletal effects of vitamin D have been examined for many years, while non-skeletal effects are being investigated.

Vitamin D plays an essential role in the maintenance of calcium and phosphorus homeostasis, consequently affecting bone formation. Calcium and phosphorous absorption from nutritional sources is poor, only $10-15 \%$ of calcium and $60 \%$ of phosphorous are absorbed, while at optimal vitamin D concentrations, the absorption of calcium and phosphorous is $30-40 \%$ and $80 \%$, respectively (19). During certain periods when there is an increased need for $\mathrm{Ca}^{2+}$, such as during development, pregnancy and lactation, $60-80 \%$ of $\mathrm{Ca}^{2+}$ in food can be absorbed if the vitamin D status is sufficient; the status is sufficient when there is an the increased concentration of circulating 1,25-dihydroxyvitamin D, which reflects the extent of mineral absorption (1). The role of vitamin $\mathrm{D}$ in the prevention of bone diseases was established for different ages. A meta-analysis of the effects and dose dependence of vitamin D with or without calcium supplementation on non-vertebral and hip fractures in older subjects showed a risk reduction of $29 \%$ for non-vertebral fractures and $15 \%$ for hip fractures. It was also observed that these effects were not calcium dependent, this conclusion was confirmed three years later by Bischoff-Ferrari, who performed a meta-analysis of vitamin D supplementation at a daily dose of $800 \mathrm{IU}(10,20)$. Conflicting data emerged from studies that analysed the effects of supplementation at higher doses (ranging from 20000 to 50000 IU weekly), which could explain the different respondents' characteristics $(21,22)$. The results from a cross-sectional study confirmed the existence of correlations between calcitriol levels and bone mineral density and fracture incidence; the limit of the concentration of $25(\mathrm{OH}) \mathrm{D}$ for a positive correlation ranged from 20 $\mathrm{ng} / \mathrm{mL}$ to $36 \mathrm{ng} / \mathrm{mL}$ depending on the examined population and the geographical position of participants whose mineral density was measured (23). It is noteworthy that vitamin D supplementation in large annual doses could impair bone health and lead to unexpected effects (23). This evidence should prompt all healthcare professionals to search all literature when considering doses for vitamin D supplementation.

The vast number of non-skeletal effects of vitamin $\mathrm{D}$ is explained by the presence of the vitamin D receptor (VDR) in most tissues and organs in the body. Another potential theory, in addition to the vitamin $\mathrm{D}$ receptor, is that after the $25(\mathrm{OH}) \mathrm{D}$ level reaches a value over $30 \mathrm{ng} / \mathrm{ml}$, there is enough substratum for the local production of the active metabolite $1,25(\mathrm{OH})_{2} \mathrm{D}$ in the colon, skin, prostate, lung and other non-renal tissue. It is now known that the aforementioned metabolite has the ability to inhibit cell proliferation and induce terminal differentiation as well as to decode genetic information for several hundred genes (2). 
Cancer diseases are one of the leading causes of mortality in the world, according to the World Health Organisation; 19,3 million new cases are anticipated to emerge per year until 2025. There is evidence that vitamin D contributes to these pathological conditions, which underlines the importance of adequate vitamin D supplementation in this patient population (24). Epidemiological research on the influence of sunlight on cancer has been conducted since 1936 in the USA. Different studies such as case control and prospective and retrospective trials have affirmed the connection between vitamin D and 15 different types of cancer where the anticancer mechanism of vitamin D by VDR is associated with the regulation of proliferation, differentiation, apoptosis and angiogenesis in normal and cancerous cells $(25,26)$. Data from the study that examined risk from breast cancer, one of the most common disorder of this type, observed a risk reduction for almost $58 \%$ at $25(\mathrm{OH}) \mathrm{D}$ level $>38 \mathrm{ng} / \mathrm{ml}(27)$.

Vitamin D impacted to cardiovascular disease prevention due to the availability of VDR on the endothelium and vascular smooth muscle and cardiac muscle cells. The anti-atherosclerotic effects of vitamin D included the inhibition of the foam cell formation and smooth cell proliferation, the expression of adhesion molecules on endothelial cells and the release of inflammatory mediators (28). Vitamin D also affects hypertension, one of the most common non-communicable diseases. Hypotensive effects occur due to the inhibition of the renin-angiotensin system in the juxtaglomerular apparatus of the kidneys i.e. due to the down-regulation of renin gene transcription by $1,25(\mathrm{OH})_{2} \mathrm{D}$. The inhibition of renin expression by calcitriol occurs due to the binding to the transcription factor cAMP-CRE- binding protein, which disables renal transcription. The prevention of primary hyperparathyroidism and the regulation of calcium metabolism are complementary mechanism of the hypotensive effect $(29,30)$. Clinical experience about this hypotensive is controversial and results from meta-analyses that show a negative correlation between serum calcidiol level and blood pressure. The results of a multicentre clinical trial may provide more detailed information (31).

Studies that evaluated the influence of vitamin D on the development and modification of clinical pathways of autoimmune disorders have presented positive results regarding the significance of vitamin D in cytokine production, in inflammation decreasing and the induction of immune cells. It is well known that this vitamin increased the quantity of Th2 lymphocytes and exerted immunoregulatory and anti-inflammatory effects via the induction of dendritic cell proliferation $(32,33)$. The influence of vitamin D on autoimmune processes has most often been evaluated in disorders such as diabetes, multiple sclerosis, rheumatoid arthritis and Crohn's disease. A randomised, placebo controlled study revealed that participants with multiple sclerosis who take vitamin D at a daily dose of 1000 IU, apart from an increase in calcidiol levels, had a higher level of transforming growth factor (TGF)- $\beta 1$, which is an an- ti-inflammatory cytokine. This result was in accordance with observations in a cohort study in which vitamin D3 at a higher daily dose of $20000 \mathrm{IU}$, influenced the function of CD4 ${ }^{+} \mathrm{T}$ cells $(34,35)$.

The presence of the VDR on beta cells in the pancreas, the stimulatory influence of calcitriol on insulin secretion, the decrease in insulin resistance in muscles as well as the reduction in inflammation that occur during insulin resistance are some of the reasons why vitamin D has potential for diabetes prevention (23).

The two most important factors for the involvement of vitamin $\mathrm{D}$ in brain development and physiological brain functions are the existence of $1 \alpha$-hydroxylase and VDR in the human brain. Cognition, Alzheimer's disease, anxiety, and depression are some of the conditions in which the connection between vitamin $\mathrm{D}$ and disease pathophysiology have been examined.

It is well known that the activation and inactivation of vitamin D occur in the brain. The hypothalamus and substantia nigra are the two regions of the brain where 1,25-dyhidroxyvitamin $\mathrm{D}$ is produced due to the presence of the CYP27B1 enzyme. The positive effects of vitamin D in the brain could be explained by the presence of the vitamin D receptor in most neurons and certain glia and the impact of vitamin D on gene regulation that influences the expression of nerve grow factor and neurotrophin 3 and that affects neuroimmunomodulation processes (36).

The hypothalamus and limbic system are connected with the pathophysiology of depression, and the presence of vitamin D receptors and hydroxylation enzymes in the aforementioned areas may indicate a connection between vitamin D deficiency and this disorder (37). One constraint of this assertion is the presence of divergent results from studies with different methodological and experimental approaches in subjects with anxiety or depression and healthy participants $(38,39)$.

Autism, one epidemic condition that is diagnosed in childhood, may be correlated with vitamin D deficiency and hypovitaminosis $\mathrm{D}$ during the prenatal period or during early childhood. Hypovitaminosis D is recognized as one of the potential risk factors for autism, and this hypothesis is based on evidence from epidemiological and clinical examinations (40). However, research on this topic is preliminary, and more extensive studies should be conducted in the future (41).

\section{PHARMACOKINETICS}

Pharmacokinetic processes of vitamin D are well known because of a large number of studies with radiolabelled vitamin D3 in both humans and animals, which can considerably facilitate the clinical application of vitamin D according to the characteristics of an individual.

The proximal part of the small intestine is the location where the majority of vitamin D absorption occurs. An essential factor for this process is the presence of normal bile 
acid secretion due to the lipophilic structure of vitamin D. Bile acid is an indispensable factor for the incorporation of nonpolar molecules of vitamin $\mathrm{D}$ into the micelles of bile salt, after which it can be absorbed into the liquid phase. Normal stomach and pancreas secretion and diffusion through the liquid layers are additional factors for this pharmacokinetic step. In compliance with the aforementioned factors, the cause of reduced absorption is clear in intestinal diseases such as biliary obstruction, chronic pancreatitis, Crohn's disease, renal insufficiency, etc. (42, 43). The effect of malabsorption syndrome on vitamin D absorption was evaluated by Satia and co-workers, and their results indicate that vitamin D3 absorption was higher in healthy subjects than in patients with malabsorption disease (44).

The following pharmacokinetic step, distribution, begins after the absorption of exogenous vitamin $\mathrm{D}$ in the small intestine. Distribution occurs due to the transfer of absorbed vitamin D into the lymphatic system. Vitamin D is then transported to circulation and binds to the vitamin $\mathrm{D}$ binding protein after which the resulting complex continues to the liver. Because the vitamin $\mathrm{D}$ binding protein is a key substance for distribution, it should be noted that hepatic impairment, nephrotic syndrome and malnutrition negatively impact distribution while pregnancy and estrogen therapy have contradictory effects (45).

The metabolic pathway of vitamin D consists of two hydroxylation reactions that take place in the liver and kidneys in the presence of cytochrome P450 enzymes that function as oxidases, including $25 \alpha$-hydroxylase, a 27A1 cytochrome $\mathrm{P} 450$ isoform, and $1 \alpha$-hydroxylase, a CYP27B1 isoform. These reactions are crucial for the creation of a physiologically active vitamin D form. Eexperiments have demonstrated that hydroxylation in the liver proceed by first order kinetics and that $75 \%$ of the total amount of vitamin D consumed, whether it is exogenous or endogenous, undergoes first pass metabolism through the liver (8). The final outcome of the first hydroxylation reaction in the liver is the formation of 25-hydroxyvitamin D, which is the inactive form. Enzyme $25 \alpha$-hydroxylase is also detected in the skin, the kidneys and the intestines but in far less quantities. After calcidiol formation, the vitamin binds to the vitamin $\mathrm{D}$ binding protein and is carried to the kidneys where it is filtered and reabsorbed in the proximal renal tubules. The available data established the presence of the cell surface receptors megalin and cubulin, which facilitate the endocytosis of calcidiol-VDBP by renal cells and other cells in the human body (46). Renal hydroxylation of calcidiol by $1 \alpha$-hydroxylase forms calcitriol, a more polar and biologically active product of the second metabolic reaction. Particularities of these two hydroxylation reactions are not only specific to the type of enzyme but also depend on endocrine mechanisms. An interesting observation is that the formation of $25(\mathrm{OH}) \mathrm{D}$ is independent of endocrinology and occurs exclusively in response to the concentration of available vitamin $\mathrm{D}$, this attribute can be another reason for the consensus about a key marker for the determination of vitamin D status in individuals (47).

Apart from the hydroxylation enzymes, 24-hydroxylase is important for vitamin D metabolism, and its role is reflected in the catabolism of both vitamin D metabolites. Metabolic pathways of ergocalciferol and cholecalciferol are intertwine, but studies based on the clinical examination of differences after oral ingestion of these two forms have noted the controversial results.

Vitamin D is excreted predominantly via the bile and faeces, and a smaller portion is excreted through the urine (6).

\section{FACTORS RELATED TO VITAMIN D DEFICIENCY}

Because the cutaneous production of vitamin D is a crucial step for the generation of an adequate vitamin D level, it is important to examine overarching factors that can influence this stage. These factors involve the season of the year, geography, clothing style, age, gender, skin type, obesity, sun exposure time, using of sunscreen, etc. (48).

Important factors that have an enormous influence on vitamin D3 synthesis are the time of day when skin is exposed to the sun light, the time of the year and the geographical position, i.e. the latitude because these factors determine the solar zenith angle, and it is well known that a smaller solar zenith angle is linked to intensive UV radiation (49). A combination of factors that can create unfavourable conditions for vitamin D production at some period of the year in a country with a latitude below $35^{\circ}$ can be present during most of the year, while for higher latitudes value can exist during the winter months. Serbia is a country that extends into the Balkan Peninsula, and the geographical position between $41^{\circ} 53^{\prime}$ and $46^{\circ} 11^{\prime}$ impedes vitamin D production from April to October, (50). Bandeira and co-workers has shown that countries with a lower latitude position exhibit a high prevalence of vitamin D deficiency, from $50 \%$ to $97 \%$ (51).

In order to assess the real picture of deficiency, many studies were performed at different locations worldwide, and these results were also devastating. In the United Kingdom, the prevalence of vitamin D deficiency in the general population was $87,1 \%$, in Germany, the prevalence was $50 \%$, in Spain, the prevalence was $33,9 \%$, and in Italy, the prevalence was $17 \%$ (52-55). A report from the International Osteoporosis Foundation about hypovitaminosis D in Europe reported concentrations of $25(\mathrm{OH}) \mathrm{D}$ of $<25 \mathrm{nmol} / \mathrm{l}$ in 2 to $30 \%$ of the adult population and $75 \%$ of the geriatric population (56). Alarming data were shown in a cross-sectional study of the adolescent population in ten European cities where hypovitaminosis D was present in $80 \%$ of the evaluated population, and almost $40 \%$ of individuals exhibited deficiency (35). Medical students were also part of the hypovitaminosis D framework in several countries such as Saudi Arabia, Spain and Serbia (52, $58,59)$. A recently conducted cross-sectional study in the 
Table 1. Vitamin D status at the Southeast Europe country

\begin{tabular}{|c|c|c|c|c|c|c|}
\hline Country & $\begin{array}{l}\text { Year of the study } \\
\text { conduction }\end{array}$ & Population & $\begin{array}{l}\text { Number of } \\
\text { participants }\end{array}$ & $\begin{array}{l}\text { Mean 25(OH)D } \\
\text { level }\end{array}$ & $\begin{array}{l}\text { Percentage } \\
\text { of vitamin } \\
\text { D deficiency } \\
\text { patients }\end{array}$ & Season \\
\hline \multirow[t]{2}{*}{ Bulgaria $^{61,62}$} & 2014 & $\begin{array}{l}\text { Adults patients } \\
\text { with chronic } \\
\text { hepatitis } C \text { viral } \\
\text { infection }\end{array}$ & 296 & $50.40 \mathrm{nmol} / \mathrm{l}$ & $49 \%$ & Winter \\
\hline & 2012 & Adults & 2032 & $38.75 \mathrm{nmol} / \mathrm{l}$ & $21,3 \%$ & Winter \\
\hline \multirow[b]{2}{*}{ Croatia $^{63,64}$} & 2013 & $\begin{array}{l}\text { Postmenopausal } \\
\text { women }\end{array}$ & 194 & $49.1 \mathrm{nmol} / \mathrm{l}$ & $29.6 \%$ & N.A. \\
\hline & 2013 & $\begin{array}{l}\text { Adults with acute } \\
\text { coronary } \\
\text { Syndrome }\end{array}$ & 60 & $34.9 \mathrm{nmol} / \mathrm{l}$ & $76 \%$ & N.A. \\
\hline Romania $^{65}$ & From 2012 to 2014 & $\begin{array}{l}\text { Very young and } \\
\text { very old }\end{array}$ & 6631 & $29.95 \mathrm{ng} / \mathrm{ml}$ & $26.1 \%$ & All seasons \\
\hline Serbia $^{60}$ & 2012 & $\begin{array}{l}\text { Young, healthy } \\
\text { adults }\end{array}$ & 86 & $13.26 \pm 4.86 \mathrm{ng} / \mathrm{ml}$ & $88.37 \%$ & Summer \\
\hline
\end{tabular}

Shumadia region on healthy medical students showed a significant presence of vitamin D deficiency (60). Several reports about the status of this vitamin from studies conducted in Southeast European countries in various population groups are shown in Table 1 (60-65).

Currently, computer models created by researchers have been used to determine the amount of UVB radiation required to achieve an adequate level of vitamin $D$ in individuals according to their skin type and place of residence, but the existence of the above mentioned factors disable the use of these software programs in clinical practice (14).

Society modernization and health education about skin care and harmful sun influence that can be reduced by using cosmetics products with the appropriate sun protection factor (SPF) have led to the occurrence of a heliophobic attitude in both females and males, which has created suitable conditions for vitamin D deficiency (66). An interesting observation from a descriptive study that was carried out in London was that participants were not aware that sunscreen preparation blocked vitamin D synthesis (67).

Human aging leads to a decreased concentration of 7-dehydrocholesterol, which consequently negatively impacts the process of vitamin D synthesis. Study data indicate that the capacity is reduced to almost a quarter after 70 years compared to young adults (49).

Skin type varies from nation to nation, and dark skin requires much more UVB radiation than lighter skin, which is experimentally affirmed due to the large amount of melanin that absorbs UVB light and consequently decreases the availability of vitamin D3 (68).

A number of studies indicate that gender affects levels of $25(\mathrm{OH}) \mathrm{D}$, whereby higher levels are recorded in men; this is scientifically explained by the greater amount of adipose tissue in a woman's body that can sequester endogenously produced vitamin $\mathrm{D}$ and can store this vitamin in humans (69). Nevertheless, research that has examined correlations between vitamin $\mathrm{D}$ serum levels and body mass index showed opposing results (70).

Apart from fat cells, vitamin D made in excess can be stored in the muscles, liver or skeleton, which prevents the attainment of a toxic dose during supplementation. This knowledge about fat storage in vitamin D created confusion regarding the sudden release of vitamin $\mathrm{D}$ deposits in some situations such as weight loss, for example, whether this leads to a toxic dose in the human body. The results from studies have not confirmed this theory until now, and experimental research performed with radiolabelled vitamin $\mathrm{D}$ has shown that the adipose storage process is not indefinite and even this process is associated with the halflife of vitamin D in the whole body (71).

\section{VITAMIN D DEFICIENCY}

Vitamin D deficiency is a problem that has existed since the early years of the 19th century with the emergence of the migration of populations from rural to urban regions, and this problem still exists all around the world in accordance with technology, modernization and lifestyle changes. All types of individuals are vulnerable to vitamin D deficiency, not only children as was considered earlier. Deficiency in children is associated with rickets, and deficiency in adults and older individuals is associated with osteomalacia, osteoporosis and consequently bone fracture (9).

Evidence from studies shows the significance of raising awareness about the influence of vitamin D deficiency on health status in the general population; 25-hydroxyvitamin $\mathrm{D}(25(\mathrm{OH}) \mathrm{D})$ levels that represent normal, physiological, values of vitamin $\mathrm{D}$ are linked with risk reduction for the above mentioned diseas- 
es are in the range of $30 \mathrm{ng} / \mathrm{ml}$ up to $50 \mathrm{ng} / \mathrm{ml}$. Values of $25(\mathrm{OH}) \mathrm{D}$ below $20 \mathrm{ng} / \mathrm{ml}(50 \mathrm{nmol} / \mathrm{l})$ indicate vitamin $\mathrm{D}$ deficiency. However, the value of vitamin $\mathrm{D}$ that would separate hypovitaminosis D from the optimal status was discussed by a large number of scientists in this field, and they agreed on this value (72). The evaluation of the precise $25(\mathrm{OH}) \mathrm{D}$ concentration that separates inadequate (deficiency or insufficiency) concentrations from the optimal concentration is most frequently performed by monitoring the concentrations of parathyroid hormone (PTH) and calcidiol, which are negatively correlated to these two parameters. Experimental findings are in favour of this inverse correlation until the level of calcidiol reaches the range of 75 to 100 $\mathrm{nmol} / \mathrm{l}$, after which the level of PTH is stabilized to the reference values (73). An additional criterion that was measured for this calculation includes the increase in intestinal calcium absorption. It has been reported that it was only when the calcidiol concentration reached levels of 50-80 nmol/l that there was an increase in absorption from $45 \%$ to $65 \%$, which could be of great clinical significance (74). The deficiency level was defined in agreement with the results of a study in which healthy participants received vitamin D2 supplementation at a weekly dose of 50000 IU for eight weeks, which was followed by a decrease in the PTH level of $35 \%$ in subjects who had a level of $25(\mathrm{OH}) \mathrm{D}$ of less than $20 \mathrm{ng} / \mathrm{ml}(75)$. This cut-off value was defined as a deficiency, and values from 21 to $29 \mathrm{ng} / \mathrm{ml}$ ( 50 to $75 \mathrm{nmol} / \mathrm{l}$ ) were defined as an insufficiency, while values from 30 to $100 \mathrm{ng} / \mathrm{ml}$ (75 to $250 \mathrm{nmol} / \mathrm{l}$ ) were defined as being at an optimal level. Specified levels are in conformance with recommendations from the American Institute of Medicine (76). The adequacy of the proposed cut-off values for vitamin $D$ status are justified with observations from prospective, clinical studies of participants with different pathological entities such as colorectal carcinoma, diabetes mellitus, etc. (77).

Vitamin D intoxication was identified at a $25(\mathrm{OH}) \mathrm{D}$ level of $>150 \mathrm{ng} / \mathrm{ml}(1,2)$. Hypercalcaemia is one of the adverse effects of vitamin D use, and it occurs due to increased intestinal calcium absorption and decreased renal excretion because of vitamin D supplementation and bone remodelling (77).

The exact number of people in the world with vitamin D deficiency is difficult to determine because of the inconsistency of cut-off values that some laboratories are using despite recommendations. Current epidemiological data indicate that vitamin D deficiency or insufficiency exists in approximately 1 million people, which is an alarming fact (9). Therefore, most developed countries recognize the scope of this problem and are implementing procedures to improve vitamin $\mathrm{D}$ status, including the use of food fortification or explicitly defining supplementation doses for specific groups such as children, adolescents, pregnant women, elderly people, patients with chronic diseases, etc.

\section{GUIDELINES}

According to the results of clinical studies, the upper limit of the vitamin $\mathrm{D}$ dose that has no connection with harmful effects ranges from $50 \mu \mathrm{g} /$ day (2000 IU/day) to $100 \mu \mathrm{g} /$ day, which is a valid recommendation in Europe and North America (18).

Consistent with the scientific evidence presented by Holick et al., a supplemental dose of 10000 IU/daily of vitamin D in individuals without adequate sunlight exposure is safe, but the authors recommend a daily dose of 1000-2000 IU of vitamin D; therapeutic doses are larger (9). Moreover, a recommendation by the same author is that requirements for vitamin $\mathrm{D}$ can be met in the Caucasian population by exposing $10-15 \%$ of the skin area such as the neck, head, arms and legs to sun for 10-15 min daily or 2-3 times weekly from 10 a.m. to 3 p.m. (50). This statement should be taken with some reservation due to the previously mentioned factors that determine the quantity of synthesized vitamin $D$.

\section{CONCLUSION}

Vitamin D deficiency is a key public health issue worldwide that requires comprehensive analyses to construct international guidelines for vitamin D supplementation that will decrease the proportion of adverse effects of vitamin D deficiency. A sedentary lifestyle and heliophobic behaviour should be starting points that need to be eradicated in order to achieve optimal vitamin D levels in individuals.

The available literature suggests contradictory conclusions about vitamin D supplementation that may confer benefits in humans. Furthermore, more systematic reviews to unify and analyse the results and the validity of numerous studies of vitamin D around the world are needed.

\section{REFERENCES}

1. Holick MF. Sunlight and vitamin D for bone health and prevention of autoimmune diseases, cancers, and cardiovascular disease. Am J Clin Nutr 2004;80(6 Suppl):1678S-88S.

2. Holick M. Vitamin D: a D- lightful health perspective. Nutr Rev 2008;66(Suppl2):182-94.

3. Płudowski P, Karczmarewicz E, Bayer M, et al. Practical guidelines for the supplementation of vitamin D and the treatment of deficits in Central Europe - recommended vitamin D intakes in the general population and groups at risk of vitamin D deficiency. Endokrynol Pol 2013;64(4):319-27.

4. Radlović N, Mladenović M, Simić D, Radlović P. Vitamin D in the light of current knowledge. Srp Arh Celok Lek 2012;140(1-2):110-4.

5. Autier P, Boniol M, Pizot C, Mullie P. Vitamin D status and ill health: a systematic review. Lancet Diabetes Endocrinol 2014;2(1):76-89. 
6. DeLuca H. History of the discovery of vitamin D and its active metabolites. Bonekey Rep 2014;3:479.

7. Wolf G. The discovery of vitamin D: the contribution of Adolf Windaus. J Nutr 2004;134(6):1299-302.

8. Kimball S, Fuleihan Gel-H, Vieth R. Vitamin D: a growing perspective. Crit Rev Clin Lab Sci 2008;45(4):339-414.

9. Holick MF. Vitamin D deficiency. N Engl J Med 2007;357:266-81.

10. Bischoff-Ferrari HA, Dawson-Hughes B, Staehelin $\mathrm{HB}$, et al. Fall prevention with supplemental and active forms of vitamin D: a meta-analysis of randomised controlled trials. BMJ 2009;339:843-6.

11. Holick MF, MacLaughlin JA, Clark MB, et al. Photosynthesis of previtamin D3 in human skin and the physiologic consequences. Science 1980;210(4466):203-5.

12. Holick MF. Nutrition and Health: Vitamin D. In: Chen TC, Zhiren Lu, Holick MF, editors. Photobiology of Vitamin D. Springer Science Business Media 2010; 35-60.

13. Wacker M, Holick MF. Sunlight and Vitamin D: A global perspective for health. Dermatoendocrinol 2013;5(1):51-108.

14. Engelsen O. The relationship between ultraviolet radiation exposure and vitamin D status. Nutrients 2010;2(5):482-95.

15. Kovesdy CP, Quarles LD. Fibroblast growth factor-23: what we know, what we don't know, and what we need to know. Nephrol Dial Transplant 2013;28(9):2228-36; DOI: $10.1093 / \mathrm{ndt} / \mathrm{gft} 065$.

16. Japelt RB, Jakobsen J. Vitamin D in plants: A review of occurrence, analysis, and biosynthesis. Front Plan Sci 2013;4:136.

17. Spiro A, Buttriss Jl. Vitamin D: An overview of vitamin D status ant intake in Europe. Nutr Bull 2014; 39(4):322-50.

18.EFSA Panel on Dietetic Products, Nutrition and Allergies (NDA): Scientific opinion on the tolerable upper intake level of vitamin D. EFSA Journal 2012;10:2813: 1-45.

19. Nair R, Maseeh A. Vitamin D: The "sunshine" vitamin. J Pharmacol Pharmacother 2012;3(2):118-26.

20. Bischoff-Ferrari HA, Willett WC, Orav EJ, et al. A pooled analysis of vitamin $\mathrm{D}$ dose requirements for fracture prevention. N Engl J Med 2012;367(1):40-9.

21. Steffensen LH, Jorgensen L, Straume B, Mellgren SI, Kampman MT. Can vitamin D(3) supplementation prevent bone loss in persons with MS? A placebo-controlled trial. J Neurol 2011;258:1624-31.

22. Rastelli AL, Taylor ME, Gao F, et al. Vitamin D and aromatase inhibitor-induced musculoskeletal symptoms (AIMSS): A phase II, double-blind, placebo-controlled, randomized trial. Breast Cancer Res Treat 2011;129:107-16.

23. Cândido FG, Bressan J. Vitamin D: link between osteoporosis, obesity, and diabetes? Int J Mol Sci 2014;15(4):6569-91.
24. World Health Organisation. Latest world cancer statistics. Global cancer burden rises to 14.1 million new cases in 2012: Marked increase in breast cancers must be addressed. International Agency for Research on Cancer. Availabel at: https://www.iarc.fr/en/media-centre/ pr/2013/pdfs/pr223_E.pdf (Last accessed: Mart 2016).

25. Wacker M, Holick MF. Vitamin D - effects on skeletal and extraskeletal health and the need for supplementation. Nutrients 2013;5(1): 111-48.

26. Laktasic-Zerjavic N, Korsic M, Crncevic-Orlic Z, Anic B. [Vitamin D: vitamin from the past and hormone of the future]. Lijec Vjesn 2011;133(5-6):194-204.

27. Garland C, Gorham E, Mohr S, et al. Vitamin D and prevention of breast cancer: pooled analysis. J Steroid Biochem Mol Biol 2007;103:708-11.

28. Carvalho LS, Sposito AC. Vitamin D for the prevention of cardiovascular disease: Are we ready for that? Atherosclerosis 2015;241(2):729-40.

29. Ajabshir S, Asif A, Nayer A. The effects of vitamin D on the renin-angiotensin system. J Nephropathol 2014; 3(2):41-3.

30. Pilz S, Tomaschitz A, Ritz E, Pieber TR. Vitamin D status and arterial hypertension: a systematic review. Nat Rev Cardiol 2009;6(10):621-30.

31. Beveridge LA, Struthers AD, Khan F, et al; D-PRESSURE Collaboration. Effect of Vitamin D Supplementation on Blood Pressure: A Systematic Review and Meta-analysis Incorporating Individual Patient Data. JAMA Intern Med 2015;175(5):745-54.

32. Adorini L, Penna G. Control of autoimmune diseases by the vitamin D endocrine system. Nat Clin Pract Rheumatol 2008;4(8):404-12.

33. Kamen DL, Tangpricha V. Vitamin D and molecular actions on the immune system: modulation of innate and autoimmunity. J Mol Med (Berl) 2010;88(5):441-50.

34. Mahon BD, Gordon SA, Cruz J, Cosman F, Cantorna MT. Cytokine profile in patients with multiple sclerosis following vitamin D supplementation. J Neuroimmunol 2003;134:128-32.

35. Smolders J, Peelen E, Thewissen M, et al. Safety and $\mathrm{T}$ cell modulating effects of high dose vitamin D3 supplementation in multiple sclerosis. PLoS One 2010;5(12):e15235.

36. Harms LR, Burne TH, Eyles DW, McGrath JJ. Vitamin $\mathrm{D}$ and the brain. Best Pract Res Clin Endocrinol Metab 2011;25(4):657-69.

37. Dana-Alamdari L, Kheirouri S, Noorazar SG. Serum 25-Hydroxyvitamin D in Patients with Major Depressive Disorder. Iran J Public Health 2015;44(5):690-7.

38. Sepehrmanesh Z, Kolahdooz F, Abedi F, et al. Vitamin D Supplementation Affects the Beck Depression Inventory, Insulin Resistance, and Biomarkers of Oxidative Stress in Patients with Major Depressive Disorder: A Randomized, Controlled Clinical Trial. J Nutr 2016;146(2):243-8.

39. Bičíková $M$, Dušková $M$, Vítků J, et al.Vitamin D in anxiety and affective disorders. Physiol Res 2015;64 Suppl 2:S101-3. 
40. Kocovska E, Fernell E, Billstedt E, Minnis H, Gillberg C. Vitamin D and autism: Clinical review. Research in Development Disabilitis 2012;33:1541-50.

41. Stubbs G, Henley K, Green J. Autism: Will vitamin D supplementation during pregnancy and early childhood reduce the recurrence rate of autism in newborn siblings? Med Hypotheses 2016;88:74-8.

42. Fisher L, Byrnes E, Fisher AA. Prevalence of vitamin $\mathrm{K}$ and vitamin $\mathrm{D}$ deficiency in patients with hepatobiliary and pancreatic disorders. Nutr Res 2009;29(9):676-83

43. Mailhot G. Vitamin D bioavailability in cystic fibrosis: a cause for concern? Nutr Rev 2012;70(5):280-93.

44. Satia MC, Mukim AG, Tibrewala KD, Bhavsar MS. A randomized two way cross over study for comparison of absorption of vitamin D3 buccal spray and soft gelatin capsule formulation in healthy subjects and in patients with intestinal malabsorption. Nutr J 2015;14:114; doi: 10.1186/s12937-015-0105-1.

45. Dusso AS, Brown AJ, Slatopolsky E . Vitamin D. Am J Physiol Renal Physiol 2005;289(1):F8-28.

46. Jones G, Prosser DE, Kaufmann M. Cytochrome P450-mediated metabolism of vitamin D. J Lipid 2014;55(1):13-31.

47. Hossein-nezhad A, Holick MF. Vitamin D for health: a global perspective. Mayo Clin Proc 2013;88(7):720-55.

48. Nair-Shalliker V, Clements M, Fenech M, Armstrong BK. Personal sun exposure and serum 25-hydroxy vitamin $\mathrm{D}$ concentrations. Photochem Photobiol 2013;89(1):208-14.

49. Tsiaras WG, Weinstock MA. Factors influencing vitamin D status. Acta Derm Venereol 2011;91(2):115-24.

50. Holick MF. Environmental factors that influence the cutaneous production of vitamin D. Am J Clin Nutr 1995;6(3 Suppl):638S-645S.

51. Bandeira F, Griz L, Dreyer P, Eufrazino C, Bandeira C, Freese E. Vitamin D deficiency: A global perspective. Arq Bras Endocrinol Metabol 2006;50(4):640-6.

52. González-Molero I, Morcillo S, Valdés S, et al. Vitamin D deficiency in Spain: a population-based cohort study. Eur J Clin Nutr 2011;65(3):321-8.

53. Hintzpeter B, Mensink GB, Thierfelder W, Müller MJ, Scheidt-Nave C. Vitamin D status and health correlates among German adults. Eur J Clin Nutr 2008;62(9):1079-89.

54. Hyppönen E, Power C. Hypovitaminosis D in British adults at age $45 \mathrm{y}$ : nationwide cohort study of dietary and lifestyle predictors. Am J Clin Nutr 2007;85(3):860-8.

55. Carnevale V, Modoni S, Pileri M, et al. Longitudinal evaluation of vitamin D status in healthy subjects from southern Italy: seasonal and gender differences. Osteoporos international 2001;12:1026-30.

56. Mithal A, Wahl DA, Bonjour JP, et al. IOF Committee of Scientific Advisors (CSA) Nutrition Working Group. Global vitamin D status and determinants of hypovitaminosis D. Osteoporos Int 2009;20(11):1807-20.
57. González-Gross M, Valtueña J, Breidenassel C, et al. HELENA Study Group. Vitamin D status among adolescents in Europe: the Healthy Lifestyle in Europe by Nutrition in Adolescence study. Br J Nutr 2012;107(5):755.

58. Al-Elq AH. The status of Vitamin D in medical students in the preclerkship years of a Saudi medical school. J Family Community Med 2012;19(2):100-4.

59. Milovanovic OZ, Milovanovic JR, Djukic A, et al. Variation in vitamin $\mathrm{D}$ plasma levels according to study load of biomedical students. Acta Pol Pharm 2015;72(1):213-5.

60. Milovanovic O, Milovanovic JR, Djukic A, et al. Population pharmacokinetics of 25-hydroxyvitamin D in healthy young adults. Int J Clin Pharmacol Ther 2015;53(1):1-8.

61. Gerova DI, Galunska BT, Ivanova II, et al. Prevalence of vitamin D deficiency and insufficiency in Bulgarian patients with chronic hepatitis $\mathrm{C}$ viral infection. Scand J Clin Lab Invest 2014;74(8):665-72.

62. Borissova AM, Shinkov A, Vlahov J, et al. Vitamin D status in Bulgaria--winter data. Arch Osteoporos 2013;8:133.

63. Laktasić-Zerjavić N, Rukavina K, Babić-Naglić D, Curković B, Anić B, Soldo-Juresa D. [Relationship between vitamin $\mathrm{D}$ status and bone mineral density in Croatian postmenopausal women]. Reumatizam 2013;60(1):8-13.

64. Pravecek MK, Hadzibegovic I, Prvulovic Dj, et al. Vitamin D levels in Croatian patients with acute coronary syndrome. Cardiologia Croatica 2013;8(9):281.

65. Chirita-Emandi A, Socolov D, Haivas C, Calapiș A, Gheorghiu C, Puiu M. Vitamin D Status: A Different Story in the Very Young versus the Very Old Romanian Patients. PLoS One 2015;10(5):e0128010.

66. Kalra S, Aggarwal S. Vitamin D deficiency: Diagnosis and patient centred management. J Pak Med Assoc 2015; 65(5):569-73.

67. Kotta S, Gadhvi D, Jakeways N, et al. "Test me and treat me"-attitudes to vitamin D deficiency and supplementation: a qualitative study. BMJ Open 2015;14:5(7).

68. Chen TC, Chimeh F, Lu Z, et al. Factors that influence the cutaneous synthesis and dietary sources of vitamin D. Arch Biochem Biophys 2007;460(2):213-7.

69. Hovsepian S, Amini M, Aminorroaya A, Amini P, Iraj B. Prevalence of Vitamin D Deficiency among Adult Population of Isfahan City, Iran. J Health Popul Nutr 2011;29(2):149-55.

70. Cândido FG, Bressan J. Vitamin D: link between osteoporosis, obesity, and diabetes? Int J Mol Sci 2014;15(4):6569-91.

71. Vieth R. Vitamin D toxicity, policy, and science. J Bone Miner Res 2007;22 Suppl 2:V64-8; DOI: 10.1359/jbmr.07s221.

72. Zhang R, Naughton DP. Vitamin D in health and disease: current perspectives. Nutr J 2010;9:65.

73. Lips P. Relative value of $25(\mathrm{OH}) \mathrm{D}$ and $1,25(\mathrm{OH}) 2 \mathrm{D}$ measurements. J Bone Miner Res 2007;22(11): 1668-71. 
74. Heaney RP, Dowell MS, Hale CA, Bendich A. Calcium absorption varies within the reference range for serum 25-hydroxyvitamin D. J Am Coll Nutr 2003;22(2):142-6.

75. Malabanan A, Veronikis IE, Holick MF. Redefi ning vitamin D insufficiency. Lancet 1998;351:805-6.

76. IOM (Institute of Medicine) (2010). Dietary Reference Intakes for Calcium and Vitamin D. Available at: http:// www.iom.edu/ /media/Files/Report\%20Files/2010/ Dietary-Reference-Intakes-for-Calcium-and VitamiD/
Vitamin\%20D\%20and\%20Calcium\%202010\%20Report\%20Brief.pdf (Last accessed April 2016).

77. Song M, Wu K, Chan AT, Fuchs CS, Giovannucci EL. Plasma 25-hydroxyvitamin D and risk of colorectal cancer after adjusting for inflammatory markers. Cancer Epidemiol Biomarkers Prev 2014;23(10):2175-80; DOI: 10.1158/1055-9965.EPI-14-0712.

78. Vieth R. Vitamin D toxicity, policy, and science. J Bone Miner Res 2007;22 Suppl 2:V64-8; DOI: 10.1359/jbmr.07s221. 